\title{
Interpreting Toxic Masculinity in Political Parties: A Framework for Analysis
}

\author{
Oliver Daddow and Isabelle Hertner
}

\begin{abstract}
The term 'toxic masculinity' was coined in the 1990s by sociologists and psychologists. It has since been appropriated by scholars and commentators interested in gendered behaviours and outcomes in politics. However, despite the attention belatedly being paid to masculinities as part of that research, our appreciation of, specifically, toxic masculinity's part in shaping political practices remains underdeveloped. This article proposes a move in this direction by designing a conceptual framework for exploring toxic masculinity inside political parties. We adapt findings from the original toxic masculinity literature to generate a series of indicators of toxic masculinity spanning the policy and discursive aspects of party political action. We then test the framework using a paired comparison of two parties of the populist right where we might expect to see relatively high levels of toxic masculinity: the Alternative for Germany and the UK Independence Party. Our empirical findings give us confidence that drawing on the concept of toxic masculinity can provide us with novel insights into the interplay between masculinity and political party cultures. We also hope that it will inspire a significant body of new research into toxic masculinity in political parties from across the party spectrum as well as globally.
\end{abstract}

\section{Keywords}

toxic masculinity; gender; AfD; Ukip; Nigel Farage 


\section{Interpreting Toxic Masculinity in Political Parties: A Framework for Analysis}

\section{Introduction}

In politics as in society, toxic masculinity - known in Mandarin as 'straight male cancer' (Kesvani, 2018) - has become an important focus for public discussion around, as well as the theoretical and applied research into, gender-based violence, misogyny and the mistreatment of women in public life. However, for all the evidence that 'politics is still highly masculine' (Spierings et al., 2015, 13) and that toxic masculinity plays a disturbing role in shaping social relations and political conduct, the structuring effects of masculinities on politics remains a relatively fresh field of research (Connell, 2014). In that context, it is little surprise that we lack a systematic means for making sense of toxic masculinity's effects on political party practices, specifically, as opposed to those emanating from anti-feminism or hegemonic masculinity more generally (covered in the following section and see Connell and Messerschmidt, 2005; Howson, 2006; Elias, 2008; Haider, 2016, 558). This piece of exploratory research takes a step in that direction by, first, proposing a conceptual framework for interpreting toxic masculinity's influence in political party cultures and, second, testing it for concept and face validity (Gerring, 2006, 48) on two right-wing parties in Western Europe where we might expect to see gendered behaviour in its starkest forms (building on Mudde and Kaltwasser, 2015): Alternative for Germany (Alternative für Deutschland, AfD) and the UK Independence Party (Ukip).

What follows is a report into how we assembled the framework, what we learnt from the case study evidence and a critical reflection on the future research than can refine our framework. ${ }^{1}$ The opening section reviews the cross-disciplinary literature outside political science to pinpoint the essential characteristics of toxic masculinity that might be applied inside the discipline. We do this by proposing a series of indicators of toxic masculine practices in political parties, the framework for which is spelt out in the second section. The third section explains the case study selection (two parties of the populist right) and the sources on which the framework was tested. The final section reports the highlights from the findings, resulting in two mutually reinforcing claims by way of a central argument. The empirical claim is that the AfD and Ukip exhibit high degrees of toxic masculinity because,

\footnotetext{
${ }^{1}$ A provisional word on methodological orientation. We do not rule out the possibility of mapping and measuring toxic masculinity in political parties quantitatively and/or using mixed methods. However, the article's exploratory ambition lends itself to a qualitative approach that provides appropriate context, is rich in detail and opens the way for critical reflexivity on the strengths and weaknesses of the proposed framework (see conclusions), which we envisage being streamlined as new cases from around the globe are investigated.
} 
consistently through their history, the parties have, to varying degrees, reproduced all the framework's key indicators of toxic masculine behaviour. The article's central theoretical claim follows the line of reasoning in (Geva, 2018, 2) and (Bjarnegård and Murray, 2018a, 264) who urge greater attentiveness to the production and perpetuation of male power in the research into gender and politics. The purpose of this article is to stimulate a dialogue about the merits and methods of including toxic masculinity as a specific category this research.

\section{Defining toxic masculinity: cross-disciplinary insights}

The term 'toxic masculinity' was developed in the 1990s by sociologists and psychologists exploring men's relationships with their fathers (Haider, 2016, 557). It has since been picked up by myriad academic disciplines and made its way into media and public vernacular (Kesvani, 2018), making it widely applied yet frequently misunderstood. Social workers use toxic masculinity to explore sexual violence and female mental health (Bealer, 2011; Jenney and Exner-Cortens, 2018). It informs studies of networked misogyny (Banet-Weiser and Miltner, 2016), social media behaviour and depression amongst men (Parent, Gobble \& Rochlen, 2018). In applied research, clinical psychologists investigate how toxic masculinity can operate as a barrier to effective mental health treatment in prisons (Kupers, 2005). Normatively, toxic masculinity helps educate (Posadas, 2017) and inform us about young people's views on rape and violence (Elliott, 2018; Romano, 2017). Toxic masculinity has, finally, filtered into popular consciousness as a vehicle for dissecting the reproduction of masculinity in popular culture (Rackham, 2018; Birdsall and Keay, 2018; Linstead and Maréchal, 2017), on television (Mcewen, 2018), in music (Stephens, 2017) and in commercial advertising (Topping et al., 2019).

To think through the ways in which toxic masculinity can inform the study of politics we turned to the growing body of gender research on masculinities, which foregrounds 'the position of men in a structure of gender relations' (Connell, 2014, 6) and the 'practices of groups who, predominantly, hold power in institutions and public arenas' (Connell, 2014, 6). The original work on toxic masculinity was plugged into the masculinities in politics literature, proffering two insights into how we might develop a framework for investigating toxic masculinity in political parties. The first was that toxic masculinity is 'one particular performance' of masculinity (Jenney and Exner-Cortens, 2018, 411; see also Connell, 2014, 9; Parent et al., 2018, 3), located at the most corrosive and violent end (to perpetrator and victim alike) of 'hegemonic masculinity' (Schippers, 2007 - and see below). Some hallmark characteristics of toxic masculinity include 'rage' (Haider, 2016, 559), the propensity to 
bottle up emotions, gang behaviour, limited empathy for others (Romero, 2017) and 'maladaptive communication and interaction styles' in person-to-person and online discourse (Parent et al., 2018, p. 6; Banet-Weiser and Miltner, 2016). Crucially, not everyone selfidentifying as male will exhibit this 'constellation of socially regressive male traits' (Kupers, 2005, 714. See also Grant and MacDonald, 2018, 12; BBC, 2018), and those self-identifying as female can also exhibit them. This is about gender-based activity and embedded structures not biological sex.

The second and related insight on which we drew was that toxic masculinity operates as an unabashed 'project of domination at a particular moment' (Bridges and Pascoe, 2014, 249). Toxic masculinity is all about maintaining or generating a hierarchy of social and political relations that works to the material or institutional advantage of the toxic masculinist by positioning the out-groups identified above 'in terms of privilege, power, subordination, and oppression' (Ritchie, 2019). It is an exaggerated form of hegemonic masculinity, which already 'ideologically legitimates the subordination of women' (Childs and Hughes, 2018, 283 ), by enacting a double domination: of masculinity over femininity and of one type of masculinity over others.

Toxic masculinity is, therefore, 'contrasted not only with femininity, but also with subordinated or marginalized masculinities that exist in the same society' (Connell, 2014, 8). The toxic masculinist cleaves to a narrow 'standard upon which the "real man" is defined' (Kupers, 2005, p. 716; see also Stępień, 2017; Grey and Shepherd, 2012, 122), upon which he or she confers a 'position of centrality in a structure of gender relations' (Connell, 2014, 8). Significantly for the cases explored below, the toxic masculinist endorses 'misogynistic and homophobic views' along with 'sexism, heterosexism and [extreme] competitiveness' (Parent et al., 4; see also the list in Kupers, 2005, 717), conferring on 'wealthy, able-bodied, heterosexual, ethnic-majority men' advantages over these other groups (Bjarnegård and Murray, 2018b, 268). The next section explains how these insights were used to develop the framework for analysing toxic masculinity inside political parties.

\section{Toxic masculinity inside political parties: a conceptual framework}

Investigating the gender dimensions of party cultures is a difficult business for three reasons. First, parties are complex, multi-faceted organisations shaped by their historical origins, national setting, ideology and ideational traditions, leaders and leadership teams, members and, in some cases, donors (see the conclusion). These factors shape a party's official rulebook, its informal practices (Bjarnegård and Kenny, 2015), policies, and the discourses 
that constitute them. Inside political parties, informal practices and personal relationships matter a great deal, affecting everything from the selection of candidates for public office to campaigning and policy formulation. Such organisational matters differ from party to party but they can also differ within the same party across time and space (look at the pre- and post-Jeremy Corbyn Labour Party in the UK). Second, parties can be secretive about their internal 'workings'. Accessing those workings by getting to see them at 'first hand' can be tricky even for ethnographic researchers granted the necessary level of permission. This goes especially for parties of the right (our case studies below) which tend to be the most secretive, meaning that early on in the research we ruled out ethnography interviews with party leaders, elites or activists, whilst acknowledging that they may well be important at a later date. Third, and overlaying both these issues, is the observation that 'gender is not always easy to "see" in institutions' (Kenny, cited in Thomson, 2016, 277). Despite the progress made by the \#metoo movement, many victims of apparent toxic masculine behaviour still feel embarrassed and/or unempowered to come forward, while party leaderships have little interest in making such incidents public. Toxic masculinity as 'object' is, therefore, not easy to put under the metaphorical microscope.

So how did we meet the ontological challenge of researching TM inside political parties? We began on the assumption that we needed to answer three questions: (i) What is toxic masculinity and how can we process trace its effects on political parties? (ii) In terms of style and substance, to what extent do official party discourses on women, gender and minorities display elements of toxic masculinity? (iii) Where might we see toxic masculinity at work in a party's everyday practices, and how far are they promoted or tolerated by party leaderships? Following Mudde and Kaltwasser $(2015,17)$ we pitched our article as an exercise in theory- and framework-building, meaning that the empirics of the piece are necessarily concise. Like them, we drew on publicly available sources, including party manifestos, speeches, on-the-record comments, media reporting and the memoirs of nodal agents, triangulated against evidence from secondary research, insider accounts and political journalism. Table 1 lists the six primary and secondary indicators we believe are important in mapping toxic masculinity in political parties.

\section{*Table 1 about here*}

If a party displays five to six indicators, including three or more of the primary indicators, we would describe it as a party with a highly toxic masculine culture. If a party exhibits three to 
four indicators, including two or more of the primary indicators, we would characterise it as a party with a medium degree of toxic masculinity. A party displaying two indicators, including one or more of the primary indicators, it is categorised as a party with a low degree of toxic masculinity.

We should point out that this is not about the 'absence' or 'existence' of toxic masculinity but the relative strength of the various indicators because parties are dominated by men (Bale et al., 2018) and constellations of practices and 'cultural rules about what women are supposed to be' (Downing, 2018, 368). As a working hypothesis, though, we would expect toxic masculinity to be less a feature of the practices inside Europe's Green parties, which were founded on principles of gender parity and equal representation (Pruysers et al. 2017, 222) and more of a feature of the practices inside far-left parties of the conservative centre-right (Webb and Childs, 2015) and far-right of the spectrum (Immerzeel et al. 2015; Scarrow and Gezgor, 2010: 831; Poguntke et al., 2016, 672). Complicating things is that even far-right parties represent and empower women in diverse ways, including through making them party leaders and developing myriad policies for and about 'women' (Mudde, 2007, 93-95; Dietze, 2018). However, as gender experts have pointed out, 'not all women representatives are feminists' (Webb and Childs, 2015, 25) and descriptive representation does not necessarily lead to substantive representation (Bjarnegård and Murray, 2018b, 267). This makes it important to tune in to a party's everyday practices as well as their stance on female representation and officially sanctioned discourses on women and gender issues (see below plus Akkerman, 2015; de Lange and Mügge, 2015). The following section details our findings on the intensity of toxic masculinity inside the AfD and Ukip using the indicators developed in Table 1.

\section{Toxic masculinity inside the AfD and Ukip}

To elicit the relevant data from the primary and secondary sources we relied on an expanded version of the three themes used by Mudde and Kaltwasser (2015) to explore gender and the populist right: gender representation, policies on the role of women and gendered discourse. To fine-grain our framework to cater for the toxic masculinist elements of the party cultures, we decided to code and report the data around five themes which together help us understand a party's internal culture: leaders and party image; representation, party membership and recruitment; views on homosexuality; aggression and the harassment of women; and gender and Islam. As we progress through the data we show which of our indicators in Table 1 (II, $I 2$ and so on) are signalled by the qualitative data. 
Our aim in this first 'cut' of the research was to make sure we were comparing like with like, making AfD and Ukip obvious cases for comparison, both being located in Western Europe and both in the family of populist right parties which 'are, for the most part, Männerparteien [men's parties]' (Mudde and Kaltwasser, 2015, 22). Both were set up in university milieus by ultra-liberal academics opposed to the EU (Arzheimer, 2015). AfD is the younger of the two parties, launched in 2013 with Bernd Lucke, an economics professor, as its figurehead to oppose the EU and the International Monetary Fund bailout programmes for Greece and other member states, and proposing that Germany abandon the Euro. Ukip is the older party, founded in 1993 by Alan Sked, a historian at the London School of Economics, as successor to the Anti-Federalist League (AFL), which he had founded in 1991 to oppose the Maastricht Treaty, the EU and Britain's membership of the Euro (Usherwood, 2008). Both parties therefore began life as single-issue parties opposing the EU but have branched out and professionalised their operations in the manner of more conventional parties. In line with populist right parties, the AfD and Ukip style themselves 'as saviours and protectors of a nation in danger' (Erel, 2018, 173) from mass immigration and as a voice for those voters who 'feel that the protection of ethnic minorities, gay and lesbian people, and also women' has 'gone too far' (Goodwin and Milazzo, 2015, 91).

\section{Leaders and party image}

The party leadership stories of the two parties proved revealing. As with many European radical right parties, Ukip and the AfD (Geva, 2018, 3-4) are disproportionately male-led and supported. Since its launch in 2013, the AfD has had three different leadership teams of up to three people. Between 2013 until 2017, one woman, Frauke Petry, was one of the co-leaders. However, Petry left the AfD after she got elected into the Bundestag in 2017, it later emerging that her decision had to do with the AfD's tolerance of far-right extremist candidates (Zeit Online, 2017) (I5). In the AfD's Bavarian regional association a female candidate, Corinna Miazga, decided to run for one of the deputy party leadership posts. In her speech to the party conference, she explained: 'The second reason why I am here is my colleague Petr Bystron, who during the election campaign, alerted me to the fact that women like I should really be pole dancers' (Welt.de, 2017). In the end, Miazga was not elected, only men were (I2).

During its 25-year history, Ukip has had 14 leaders (some of them acting leader and some, such as Nigel Farage, serving more than one stint) and 11 deputy leaders (I4). Of these, all but two have been male, with women holding office only briefly. Diane James led the 
party for 18 days between September and October 2016 (Wilkinson, 2016). Meanwhile, Margot Parker was Henry Bolton's deputy from September 2017 to January 2018 (Kentish, 2018). It was not until 2014 that women were incorporated in a systematic way into Ukip's decision-making 'cabinet', but the sense was that these were 'cosmetic' appointments to Farage's 'one-man band', designed to attract younger and female voters (Graham, 2014) (I4).

A good summary of Ukip's party image, and its attraction to its voters yearning for a by-gone era (Goodwin and Milazzo, 2015, 103; Clarke et al, 2016) (I1) comes from Farage himself, who has admitted $(2015,172)$ that 'On a bad day, UKIP can look so blokeish - and I am as much to blame for that as anyone else' (I4). On defecting from Ukip to the Conservatives in 2013, Marta Andreasen, then Ukip's only female MEP (Sherman, 2013) described how Farage 'doesn't try to involve intelligent professional women in positions of responsibility in the party. He thinks women should be in the kitchen or in the bedroom' (quoted in Lambert, 2014. See also Tapsfield, 2014) (I6). Farage has gone on record with denigrating comments about women and their appropriate place in society. For instance, in his memoirs he described Baroness Cathy Ashton, the EU's former EU High Representative for Foreign Affairs and Security Policy, for being 'a woman who had married well' (Farage, 2015, 161) (I2). He has, furthermore, used his regular national radio platform to suggest that mothers should 'perhaps sit in the corner' when they breast-feed so they are not 'overly ostentatious' (quoted in Wintour and Mason, 2014) (IO). Accompanying a socially conservative rhetoric, as Ukip leader (and afterwards as Brexit Party leader) Farage made a macho virtue of English 'low' vices (see Geva, 2018, 5), associated with the everyday 'working man', such as swilling copious quantities of beer - Ukip is the self-styled 'political party of the pub' (Save The Pub, 2018) - gambling and heavy smoking (Goodwin and Milazzo, 2015, 8) (I6). Conformity with what the AfD and Ukip see as 'liberal' metropolitan outlook and codes of behaviour are as anathema to the leadership as they are to those who join and vote for the parties, discussed next.

\section{Representation, membership and recruitment}

Amongst German parties in 2016, the AfD had the lowest share of female members at $16 \%$ (Niedermayer 2017). At 25\%, Ukip had the lowest share of female members amongst Britain's major parties in 2017 (Audickas et al., 2017, 17). The year before, Ukip ‘was by far the least representative party with just $14 \%$ women candidates and $20 \%$ women in their target seats' (Kelly and White, 2016, 5-7). Unsurprisingly, then, the majority of elected AfD and Ukip politicians are also male. For instance, only 10.86 percent of the AfD's Members of 
Parliament (MPs) that were elected in 2017 were female (whilst the overall share of female MPs of the 2017 Bundestag was 30.9 per cent).

Both parties reject the idea of gender quotas and female shortlists (I4). The AfD strongly opposes 'gender-ideology' because it 'marginalises the natural and inevitable differences between the sexes' (AfD 2016, 109). The party claims to favour gender equality in the sense of equal opportunities but is against promoting equality of outcomes. It opposes gender quota for businesses and the public sector, arguing that they are 'anti-competitive, unfair, and create other disadvantages' (AfD, 2016, 110) (I4). In an indication of the beliefs behind the practice, Heiner Merz, a regional MP for Baden-Württemberg, has said that gender quota only serve 'unqualified, dumb, lazy, ugly and disgusting women; the good, hard-working, and adequately qualified ones have found and will always find their way' (Muschel, 2018) $(I 2, I 4, I 5)$. This approach, it has been pointed out, constitutes 'the affectively charged fiction of [workplace] discrimination against white middle class men' (Women's Studies International Forum, 2018, 140).

Ukip's rejection of increasing female representation in politics is rooted in its belief that it is rising 'above gender politics in our fight to move Britain forward' (Bolter, cited in Mostrous and Kenber, 2014) (I4). Ukip has thereby stood out as one of the least diverse political parties even against a parliamentary system (Lovenduski, 2012) that historically has proven 'a hindrance to female representation in general' (Harrison, 2010, 524 Chappell, 2002), even if the introduction of all-women shortlists such as the SNP and Labour Party have had a noticeable effect (Kenny, 2017; Harrison, 2010). Whilst Ukip has never had more than two MPs sitting in the House of Commons, both of which were male, the party was more successful in winning seats in the European Parliament (MEPs). Out of Ukip's 24 MEPs that were elected in 2014, merely seven (25 per cent) were female. By comparison, 41 per cent of the UK's MEPs elected in 2014 were female (Hawkins and Miller, 2014, 31). Ukip's policies on gender representation reflect two mutually reinforcing strands of thought: first, from Farage, that the idea of workplace discrimination has been overplayed because 'women who are prepared to sacrifice the family life and stick with their careers do as well, if not better, than men' (quoted in Evening Standard, 2014) $(I 2 ; I 4)$; and second, because inequality is part and parcel of the society in which we live, Ukip stands against minorities 'protected' by over-bearing, contemporary political correctness ('the disabled, ethnic minorities, women and the Gay [sic] community') (Etheridge, 2014, 25) (I2). 
Representatives and members of both parties are clearly uncomfortable with homosexuality, which challenges their 'traditional version of the family' (Erel, 174) as well as what it means to be the traditional 'man' they see as preventing from 'losing out' in modern society (AfD, 2017, 38) (I1). As the AfD's Björn Höcke expressed it at a party rally in November 2015: 'We need to rediscover our masculinity. Because only if we rediscover our masculinity do we become manful. And only if we become manful, do we become fortified, and we need to become fortified, dear friends (Höcke, 2015) (I1).

The AfD is, consequently no promoter of LGBT rights, calling for the preservation of 'the traditional family', made up of father, mother, and, ideally, several children (AfD 2016, 80 ), aiming to protect 'the future of the nation's legitimate, i.e. white, heterosexual, children' (Erel, 2018, 174) (II). The party opposes same-sex marriage, which was introduced in Germany in 2017. It is also against what it calls 'a one-sided accentuation of homosexuality and transsexuality' at school, which, the AfD claims, can destroy the traditional image of the family and can make children 'the pawn of the sexual orientations of a minority (AfD 2016, 107). Reflecting this are the strongly homo/transphobic tendencies inside the AfD. For example, Höcke has declared that homosexuality is to be tolerated but not accepted: 'Accepting means approving it, which is a positive attribution. This is something that is already practiced in our schools, that this sexuality, this homosexuality is not taught as something tolerable or necessary, but as something that is deemed exclusive, desirable. Here, as a conservative party, we have to say: no' (cited by Röhling, 2018). We cannot verify the number of LGBT AfD members, nor do we have first-hand accounts of their individual experiences, so we do not know whether, or to what extent, they feel excluded or discriminated against. What we do know, however, is that the AfD's two previous LGBT working groups were dissolved (Rafael, 2018). It means that there is currently no official LGBT group inside the AfD, unusually for a German party.

In this context it is noteworthy that the party has promoted Alice Weidel, an openly gay female, to be leader of the opposition and co-chair of the party group in the Bundestag. The AfD has also begun presenting itself as the defender of Western liberal values in support of the LGBT community vis-à-vis Muslims, reinforcing the idea (developed below) that its anti-Muslim agenda trumps its positions on such matters as homosexuality and women's rights. For instance, in its membership magazine, AfD Kompakt, the party cites AfD politician Harald Feineis from Hamburg who argues: 'We are the only party that is brave enough to call out the root causes for the fast increasing numbers of verbal or violent attacks against homo-, inter-, and transsexuals by their name: the largely uncontrolled mass 
migration of fanatic Muslims from patriarchal clan-societies with strongly homophobic tendencies' (AfD Kompakt, 2018). The AfD's LGBT-friendly statements are, it appears, instruments through which it justifies and promotes its Islamophobia.

Ukip's stance is, on the surface at least, softer than the AfD's by: 'In Britain, we do not believe in treating women or gay people as second-class citizens' (Ukip, 2017, 34). However, prominent Ukip politicians such as Helmer have described homosexuality as 'abnormal and undesirable' - 'not a valid lifestyle' (quoted in Hope, 2014) (II). Farage has excused Helmer using one of his stock excuses for toxic utterances by Ukip politicians, councillors and workers: 'most over-70s in Britain still feel uncomfortable about homosexuality' (II). Helmer was allowed to stand in the 2014 Newark by-election, but around that time Ukip did suspend a councillor who called David Cameron a 'gay-loving nutjob' (Mason, 2014; see also BBC, 2014) (I1). Ukip leaders after Farage, such as Paul Nuttall and Henry Bolton, have continued to oppose the UK law on same-sex marriage and initiatives to promote LGBT awareness in schools on the grounds that it might 'confuse and worry' children about their sexuality (Smith 2017) (II).

\section{Aggression and the harassment of women}

Verbally and physically aggressive behaviour, including but not limited to aggression towards women, is a feature of both parties' internal cultures. According to two vicepresidents of the Bundestag, the AfD's presence has 'radically changed' the tone inside parliament, as about one third of the party group, mostly backbenchers, is very belligerent, and not just verbally (Zdf.de, 2018), particularly towards women, and individuals with an ethnic/religious minority background. Alexander Gauland, who later became AfD co-leader, said during the 2017 parliamentary election campaign that Aydan Özoguz, the German government's commissioner for integration, should be 'disposed of' in Turkey (Bender, 2017). Incidents of verbal aggression by AfD politicians have also been reported from inside Germany's regional parliaments. For example, the female president of Baden Württemberg's state parliament, called the police to remove two male AfD members who constantly shouted and interrupted plenary sessions and personally attacked the president because of her Turkish origins (Stuttgarter Zeitung, 2018) (I3, I5).

In Ukip we found similarly, that Farage permitted to flourish a party culture in which actual and threats of violence between its members were commonplace. For example the October 2016 fight in the Strasbourg parliament between Ukip MEPs Stephen Woolfe and Mike Hookem prompted Ukip's leader in the Welsh Assembly, Neil Hamilton, to bemoan 
Ukip's 'culture of abuse', including 'stuff which is being traded online' (Elgot et al., 2016) (I3). As part of a wider picture such incidents are telling. More often than not, though, Ukip's 'problem around women' (Lambert, 2014) has manifested itself in harassment, as the case of Natasha Bolter aptly illustrates. Bolter was one of Ukip's rising stars but two months after a celebrated speech to the Ukip party conference in September 2014 she left Ukip in 'disgust at what she claimed was a party riddled with racism, misogyny and sexual harassment.' During and after being interviewed to become a parliamentary candidate, Bolter was apparently propositioned for sex by Ukip's general secretary, Roger Bird, who told her that 'loads of girls' slept with men in political parties (Mostrous and Kenber, 2014. See also Swinford and Heighton, 2014). Bird was suspended and investigated by Ukip but later cleared, leaving his position by mutual consent (Goodwin and Milazzo, 2015, 203) (I2; I3).

Other examples of TM behaviour by Ukip individuals include, first of all, Godfrey Bloom, who had the whip removed following comments he made, ironically, at an event to promote the number of women in politics (Farage, 2015, 172). He called women who did not clean behind the fridge 'sluts' (BBC, 2013), having previously claimed 'no sane businessman would employ a woman of child-bearing age' (quoted in Harrison, 2010, 526) (I2). Second, former Ukip party worker Alexandra Swann recalled that her time working for Ukip MEP Roger Helmer: 'I was regularly taken to strip bars, put in a position where I felt deeply uncomfortable and was eventually sacked when I spoke out.' (Swann, 2014, emphasis added) (I2). Helmer is also on record as saying that a woman who experiences date-rape 'surely shares part of the responsibility' (quoted in Belfast Telegraph, 2011) (I2).

\section{Gender and Islam}

The parties' discourses on Islam intersect in complex ways with their gender discourses, the headline in our data being that they mobilise 'feminist-inspired concerns about gender equality' to support 'racist and anti-immigration arguments' (Sager and Mulinari, 2018, 149). Supporting the findings on populist right parties in Denmark and the Netherlands, neither the AfD nor Ukip has much truck with affirmative action or 'diversity nonsense' until it comes to Muslim women when suddenly gender equality gets embraced 'most enthusiastically as a weapon against the alleged Islamization' of their 'national [white, nativist-defined] culture' (Mudde and Kaltwasser, 2015, 28-29). The AfD portrays Muslim men as violent and oppressive perpetrators; Muslim women, meanwhile, are 'subdued' (Mayer et al, 2018, 259) and 'in need of rescue' from the 'violent patriarchies' (Sager and Mulinari, 2018, 150) which dominate them. The AfD proposes a ban for face veils in public and for women working in 
the public sector on the basis that 'the burka or niqab creates a barrier between the women carrying it and her environment and thereby hampers cultural integration and the coexistence in society' (AfD, 2016, 98-99) (I2, I4).

Ukip similarly constructs gender as a 'problem' with multiple ethnic and religious dimensions to be solved by action 'upon' women by right-thinking men. This is because the party traces many of society's problems back to 'migrants and racialised minorities' (Kuskinen, 2018, 157) practising culturally Other crimes such as Female Genital Mutilation (FGM), 'breast ironing' and honour killings (Ukip, 2017, 36). Ukip therefore rejects 'multiculturalism' (Ukip, 2015, 61; Ukip, 2017, 35) (I5) and prioritises actions to be taken specifically against Muslim females to achieve its objectives (I2). In two of the three manifestos consulted, Ukip stated that it wanted to tackle 'extremist Islam by banning the burqa or veiled niqab in public buildings and certain private buildings' (Ukip, 2010, 14). This, the party said, was as much about liberty - to prevent the de-humanising of women and oppression - as it was national security (Ukip, 2017, 37). As with the AfD, Ukip subtly discriminates between different women in society to construct a hierarchy of 'better' and 'worse' identities where gender and ethnicity intersect, promoting policies that protect the 'better' (white) identity irrespective of what that means for its anti-feminist stance in other policy realms.

\section{Conclusion}

Our headline conclusion is that the AfD and Ukip show, consistently through their histories, all six indicators of toxic masculinity in our framework. The data on the AfD and Ukip suggests the parties are noticeably concerned that traditional masculinity is under threat $(I I)$, that they tolerate a culture of the abuse and harassment of women (I2) and that they rejects positive discrimination unless gender equality is linked to immigration and the integration of Muslims in society (I4). The AfD is more openly and strongly homophobic and Islamophobic in its official discourses (mainly, its manifestos) than Ukip, but both parties operate to a clear hierarchy of 'good' and 'bad' identities, promoting and tolerating socially regressive behaviours against out-groups. They entrench and reproduce toxic masculinity's division of the world along gendered and (for parties of the right) racial lines by, for example, co-opting 'femonationalists' (Farris, 2013; Mügge and de Jong, 2013; Sager and Mulinari, 2018, 149) to act as 'fronts' for anti-immigrant and anti-Islam campaigns (as in Finland, see Kuskinen, 2018, 160-161). 
In presenting our case we are aware that it is acutely difficult to gauge the degree of toxic masculinity in any party with precision. Any study of toxic masculinity is also hampered because not all of its most deleterious effects will make it to the public domain (see the introduction), while first-hand observation is almost impossible when it comes to the informal, daily practices that make up the lived experiences inside a party's culture. So how can we now advance the research into toxic masculinity in party cultures? First, we could broaden the evidence base to include external actors that actively contribute to a party's culture and image, such as donors such as Demetri Marchessini (whose views on women are covered in Mason and Swinford, 2013) and sources such as social media, which would pick up party donors and backers such as Arron Banks (Political Scrapbook, 2017). In the case of the AfD, we could analyse the social media accounts of the influential fundamentalist Christian groups that support the party, with strongly worded opinions against abortion, homosexuality, same-sex parents and Islam. Clearly for Ukip, studying the post-Farage shift to the right under Gerard Batten would alight on a rich new seam of evidence (Lavender, 2019). Interviews and ethnographic research could certainly be used to test our framework and add to our findings.

A second way to test and refine our framework would be to research the cultures of toxic masculinity in party families and from elsewhere around the globe. Our article focused on two similar, far-right populist parties already known to have problems with women. Future research should certainly, therefore, include far-right parties but also gather evidence about the ways in which leaders and members of parties from other families on the spectrum express attitudes which map onto our framework. The connectivity between toxic masculinity, party family and their embeddedness in national settings could be a very fruitful line of enquiry, help us answer two pressing questions. First, does toxic masculinity take on different forms depending on party family? And second, is national context or party family the greater influence on observed levels of toxic masculinity in a given political party? One thing seems certain, however: toxic masculinity is an under-exploited and will be an important part of the story going forward.

\section{References}

AfD (2016) Programm für Deutschland. Das Grundsatzprogramm der Alternative für Deutschland. Available at: https://www.afd.de/grundsatzprogramm/ (accessed 11 January 2019) 
AfD (2017) Programm für Deutschland. Wahlprogramm der Alternative für Deutschland für die Wahl zum Deutschen Bundestag am 24 September 2017. Available at: https://www.afd.de/wp-content/uploads/sites/111/2017/06/2017-06-01_AfDBundestagswahlprogramm_Onlinefassung.pdf (accessed 11 January 2019)

AfD Kompakt (2018) Immer mehr lesbische und schwule Menschen schliessen sich der AfD an. 30 July. Available at: https://afdkompakt.de/2018/07/30/lesbische-undschwule-menschen-schliessen-sich-der-afd-an/ (accessed 29 December 2018).

Akkerman T (2015) Gender and the radical right in Western Europe: a comparative analysis of policy agendas. Patterns of Prejudice 49(1-2): 37-60.

Arzheimer K (2015) The AfD: Finally a Successful Right-Wing Populist Eurosceptic Party for Germany? West European Politics 38(3): 335-356.

Audickas L, Dempsey N and Keen R (2018) Membership of UK Political Parties. House of Commons Library: Briefing Paper No.SN05125, 3 September.

Bale T, Poletti M. and Webb P. (2018) A Man's Game? The Grassroots Gender Gap in Britain's Political Parties. Political Insight June: 7-10.

Banet-Weiser S and Miltner KM (2016) \#MasculinitySoFragile: Culture, Structure, and Networked Misogyny. Feminist Media Studies 16(1): 171-174.

BBC (2013) Godfrey Bloom quits as Ukip MEP after 'sluts' joke row, 24 September. Available at: https://www.bbc.co.uk/news/uk-politics-24222992 (accessed 5 January 2019.

BBC (2014) Henley-on-Thames councillor David Silvester expelled from UKIP, 4 February. Available at: https://www.bbc.co.uk/news/uk-england-oxfordshire-26034104 (accessed 5 January 2019).

BBC (2018) Toxic masculinity: life as a man isn't always easy either, 19 October. Available at: https://www.bbc.co.uk/news/world-us-canada-45908983 (accessed 28 November 2018). 
Bealer TL (2011) Of monsters and men: toxic masculinity and the twenty-first century vampire in the Twilight saga', in Anatol GL (ed) Bringing Light to Twilight. New York: Palgrave Macmillan, pp.139-152.

Belfast Telegraph (2011) Tory MEP's rape remarks condemned, 23 May. Available at: https://www.belfasttelegraph.co.uk/news/uk/tory-meps-rape-remarks-condemned28620014.html (accessed 6 January 2019).

Bender J (2017) Gauland: Özoguz in Anatolien entsorgen. Frankfurter Allgemeine Zeitung, 28 August. Available at: https://www.faz.net/aktuell/politik/bundestagswahl/afd-alexandergauland-traeumt-von-entsorgung-aydan-oezoguz-15171141.html (accessed 11 January 2019).

Birdsall N and Keay S (2018) Love Island and other reality TV shows are helping to normalise domestic abuse, The Conversation, 23 July. Available at: https://theconversation.com/love-island-and-other-reality-tv-shows-are-helping-to-normalisedomestic-abuse-100268 (accessed 29 November 2018).

Bjarnegård E and Kenny M (2015) Revealing the secret garden: the informal dimensions of political recruitment Politics and Gender 11(4): 748-753.

Bjarnegård E and Murray R (2018a) Critical perspectives on men and masculinities in politics: introduction Politics \& Gender 11(4): 264-265.

Bjarnegård E and Murray R (2018b) Revisiting forms of representation by critically examining men Politics \& Gender 11(4): 265-270.

Bridges T and Pascoe CJ (2014) Hybrid masculinities: new directions in the sociology of men and masculinities Sociology Compass 8(3): 246-258.

Cadwalladr C (2018) Threats, bullying, vindictiveness: how Arron Banks repels charges against him, Guardian, 3 November. Available at:

https://www.theguardian.com/global/commentisfree/2018/nov/03/threats-bullying-andvindictiveness-how-arron-banks-repels-charges-against-him (accessed 5 January 2019). 
Chappell L (2002) The femocrat strategy: expanding the repertoire of feminist activists. Parliamentary Affairs 55(1): 85-98.

Childs S and Hughes M (2018) 'Which men? How an intersectional perspective on men and masculinities helps explain women's political underrepresentation Politics \& Gender 14(2): 283-287.

Childs S and Webb P (2015) Sex, Gender and the Conservative Party : From Iron Lady to Kitten Heels. Basingstoke: Palgrave Macmillan.

Clarke H, Whiteley P, Borges W, Sanders, D and Stewart M (2016) Modelling the dynamics of support for a right-wing populist party: the case of UKIP Journal of Elections, Public Opinion and Parties 26(2): 135-154.

Connell R (2014) The study of masculinities Qualitative Research Journal 14(1): 5-15.

Connell R and Messerschmidt JW (2005) Hegemonic masculinity: rethinking the concept Gender and Society 19(6): 829-859.

de Lange SL and Mügge LM (2015) Gender and right-wing populism in the Low Countries: ideological variations across parties and time. Patterns of Prejudice 49(1-2): 61-80.

Dietze G (2018) Rechtspopulismus und Geschlecht. Paradox und Leitmotiv Femina Politica 27(1): 34-46.

Downing L (2018) The body politics: gender, the right wing and 'identity category violations' French Cultural Studies 29(4): 367-377.

Elgot J, Halliday J and Rankin J (2016) Steven Woolfe 'smiling and well' after alleged fight with Ukip MEP Guardian, 6 October. Available at: https://www.theguardian.com/politics/2016/oct/06/ukip-leadership-favourite-steven-woolfecollapses-in-european-parliament (accessed 5 January 2019).

Elias J (2008) Hegemonic masculinities, the multinational corporation, and the 
developmental state: constructing gender in 'progressive' firms Men and Masculinities 10(4): 405-421.

Elliott K (2018) Challenging toxic masculinity in schools and society On the Horizon 26(1): $17-22$.

Erel, U (2018) Saving and reproducing the nation: struggles around right-wing politics of social reproduction, gender and race in austerity Europe Women's Studies International Forum 68: 173-182.

Etheridge B (2014) The Rise of UKIP. Epsom: Bretewalda Books.

Evening Standard (2014) Mothers worth less in City - Farage 20 January. Available at: https://www.standard.co.uk/panewsfeeds/mothers-worth-less-in-city-farage-9071680.html (accessed 5 January 2019).

Farage N (2015) The Purple Revolution. London: Biteback Publishing.

Farris, S R (2012) Femonationalism and the "Regular" Army of of Labor Called Migrant Women. History of the Present 2(2): 184-199.

Friedman J (2018) Building better men: how we can begin to redefine masculinity Guardian, 12 March. Available at: https://blogs.spectator.co.uk/2018/05/toxic-masculinity-is-a-toxicphrase/ (accessed 29 November 2018).

Gerring, J (2006) Social Science Methodology: A Critical Framework. Cambridge: Cambridge University Press.

Geva D (2018) Daughter, mother, captain: Marine Le Pen, gender, and populism in the French National Front Social Politics. Epub ahead of print 24 December 2018. DOI: https://doi.org/10.1093/sp/jxy039.

Goodwin M and Milazzo C (2015) UKIP: Inside the Campaign to Redraw the Map of British Politics. Oxford: Oxford University Press. 
Graham G (2014) Nigel Farage reshuffle: Who are Ukip's women? Telegraph, 25 July. Available at: https://www.telegraph.co.uk/news/politics/ukip/10990094/Nigel-Faragereshuffle-Who-are-Ukips-women.html/ (accessed 5 January 2019).

Grant J and MacDonald F (2018) The New/ 'Alt' Right, Toxic Masculinity, and Violence, conference paper, Canadian Political Science Association, May-June, University of Regina, Saskatchewan.

Grey R and Shepherd LJ (2012) 'Stop rape now?': masculinity, responsibility, and conflictrelated sexual violence. Men and Masculinities 16(1): 115-135.

Harrison L (2010) Women candidates and party practice in the UK: evidence from the 2009 European elections. Parliamentary Affairs 63(3): 524-533.

Hawkins O and Miller V (2014) European Parliament Elections 2014, House of Commons Library: Research Paper 14/32, 11 June.

Hayder S (2016) The shooting in Orlando, terrorism or toxic masculinity (or both?). Men and Masculinities 19(5): 555-565.

Howson R (2006) Challenging Hegemonic Masculinity. London: Routledge.

Immerzeel T, Hilde C and van der Lippe T (2015) Explaining the gender gap in radical right voting: a cross-national investigation in 12 Western European countries. Comparative European Politics 13(2): 263-286.

Höcke B (2015) speech at AfD rally, 18 November. Available at: https://www.youtube.com/watch?v=nv33HLHWUUw (accessed 29 December 2018).

Hope C (2014) Ukip MEP who said homosexuality was 'abnormal' is party's candidate in Newark by-election Telegraph, 6 May. Available at: https://www.telegraph.co.uk/news/politics/ukip/10811738/Ukip-MEP-who-said- 
homosexuality-was-abnormal-is-partys-candidate-in-Newark-by-election.html (accessed 6 January 2019).

Jenney A and Exner-Cortens D (2018) Toxic masculinity and mental health in young women: an analysis of 13 Reasons Why. Journal of Women and Social Work 33(3): 410-417.

Kelly R and White I (2016) All-women Shortlists, House of Commons Briefing Paper No.5057, 7 March. Available at:

http://researchbriefings.files.parliament.uk/documents/SN05057/SN05057.pdf (accessed 4 January 2019).

Kenny M (2017) Who runs the world? Gender and politics in the UK and beyond', Political Insight, September, 30-33.

Kentish J (2018) Ukip thrown into further turmoil as deputy leader resigns and calls on Henry Bolton to quit Independent, 22 January. Available at:

https://www.independent.co.uk/news/uk/politics/ukip-latest-news-deputy-party-leadermargot-parker-resigns-henry-bolton-quit-a8171691.html (accessed 4 January 2018).

Kesvani H (2018) What we call 'toxic masculinity' in other languages MEL. Available at: https://melmagazine.com/en-us/story/what-we-call-toxic-masculinity-in-other-languages (accessed 17 April 2019).

Kupers TA (2005) Toxic masculinity as a barrier to mental health treatment in prisons. Journal of Clinical Psychology 61(6): 713-724.

Kuskinen, S (2018) The 'crisis' of white hegemony, neonationalist femininities and antiracist feminism. Europe Women's Studies International Forum, 68: 157-163.

Lambert V (2014) What woman could ever vote Ukip? Telegraph, 10 December. Available at: https://www.telegraph.co.uk/news/politics/ukip/11285529/What-woman-could-ever-voteUkip.html (accessed 4 January 2019). 
Lavender, J (2019) Tommy Robinson's worst misdeeds from punching 'migrants' to targeting teenager. Mirror, 11 July. Available at: https://www.mirror.co.uk/news/uk-news/tommyrobinsons-worst-misdeeds-punching-17914407 (accessed 5 August 2019).

Linstead S and Maréchal G (2017) How to overcome phallus-obsessed, toxic masculinity. The Conversation, 3 November. Available at: https://theconversation.com/how-to-overcomephallus-obsessed-toxic-masculinity-84388 (accessed 29 November 2018).

Lovenduski J (2012) Feminising British politics. Political Quarterly 83(4): 697-702.

Mason R (2014) Nigel Farage defends Ukip byelection candidate over anti-gay remarks Guardian, 11 May. Available at: https://www.theguardian.com/politics/2014/may/11/nigelfarage-defends-ukip-candidate-roger-helmer-previous-anti-gay-remarks (accessed 6 January 2019).

Mason R and Swinford S (2013) Ukip donor says women in trousers are 'hostile' and unmarried mothers need a 'smack'. Telegraph, 17 May. Available at: https://www.telegraph.co.uk/news/politics/ukip/10064185/Ukip-donor-says-women-introusers-are-hostile-and-unmarried-mothers-need-a-smack.html (accessed 5 January 2019).

Mayer, S, Ajanovic, E and Sauer, B (2014) Interections and inconsistencies: framing gender in right-wing populist discourses in Austria NORA - Nordic Journal of Feminist and Gender Research 22(4): 250-266.

Mcewen CK (2018) BBC Three's Clique explains why it's important for the show to be controversial. Digital Spy, 9 November. Available at: http://www.digitalspy.com/tv/news/a870274/clique-series-2-bbc-three-showrunnersnowflake-controversy/ (accessed 29 November 2018).

Mostrous A and Kenber B (2014) Ukip riddled with racism and misogyny, claims activist. The Times, 9 December. Available at: https://www.thetimes.co.uk/article/ukip-riddled-withracism-and-misogyny-claims-activist-qmlnnl2bttq (accessed 4 January 2019). 
Mudde C (2007) Populist Radical Right Parties in Europe. Cambridge: Cambridge University Press.

Mudde C and Kaltwasser CR (2015) Vox populi or vox masculine? Populism and gender in Northern Europe and South America Patterns of Prejudice 49(1-2): 16-36.

Mügge L and de Jong S (2013) Intersectionalizing European politics: bridging gender and ethnicity Politics, Groups and Identities 1(3): 380-389.

Muschel R (2018) AfD-Mann Merz: Frauenquote nutzt nur widerwärtigen Frauen. SWP.de, 3 December. Available at: https://www.swp.de/suedwesten/afd-politiker-wuetet-gegenfrauenquote28510152.html?utm_medium=Social\&utm_source=Twitter\&fbclid=IwAR3InbdpQOQi6G7 UmXZ4Wr1R4bFwfCjM-hqPR1XcD_88ztZMB9Oz4hV66X8\#Echobox=1543854494 (accessed 5 December 2018).

Niedermayer O (2017) Parteimitglieder in Deutschland: Version 2017 NE. Arbeitshefte aus dem Otto-Stammer-Zentrum, No. 27, Berlin: Freie Universität. Available at: http://www.polsoz.fu-berlin.de/polwiss/forschung/systeme/empsoz/schriften/Arbeitshefte/PPMIT17-NEU.pdf (accessed on 4/7/2018).

Oaten A (2018) UKIP: how the party is battling to stay relevant. The Conversation, 11 December. Available at: https://theconversation.com/ukip-how-the-party-is-battling-to-stayrelevant-108375 (accessed 8 January 2019).

Parent MC, Gobble TD and Rochlen A (2018) Social media behavior, toxic masculinity, and depression. Psychology of Men and Masculinity. Epub ahead of print Aoril 2018, DOI: $10.1037 / \operatorname{men} 0000156$.

Peterson VS (ed) (1992) Gendered States: Feminist (Re) Visions of International Relations Theory. Boulder, CO.: Lynne Reinner Publishers.

Pfahler L (2017) Wie radikale Burschenschaften zur Kaderschmiede der AfD wurden. Huffington Post, 27 July. Available at: 
https://www.huffingtonpost.de/2017/07/27/burschenschaften-afd-_n_17597626.html (accessed 2 January 2019).

Poguntke T, Scarrow SE and Webb PD (2016) Party rules, party resources and the politics of parliamentary democracies: How parties organize in the 21st century. Party Politics 22(6): 661-678.

Political Scrapbook (2017) Arron Banks: Homosexuality not 'a great lifestyle choice'. 10 August. Available at: https://politicalscrapbook.net/2017/08/arron-banks-homosexuality-nota-great-lifestyle-choice/ (accessed 5 January 2019).

Posadas J (2017) Teaching the cause of rape culture: toxic masculinity. Journal of Feminist Studies in Religion 33(1): 177-179.

Pruysers S, Cross, WP, Gauja A and Rahat G (2017) Candidate selection rules and democratic outcomes. In: Scarrow SE, Webb PD and Poguntke T (eds) Organizing Political Parties. Oxford: Oxford University Press, pp.208-233.

Rackham A (2018) Does The Only Way is Essex promote 'toxic masculinity’? BBC, 6 April. Available at: https://www.bbc.co.uk/news/entertainment-arts-43639380 (accessed 28 November 2018).

Rafael S (2018) Was finden Homosexuelle an der AfD? Belltower News, 25 April. Available at: https://www.belltower.news/was-finden-homosexuelle-an-der-afd-43614/ (accessed 29 December 2018).

Ritchie K (2019) Neither fate nor fiction: finding social groups in networks of social relations The Philosopher 107(3). Available at: https://www.thephilosopher1923.org/ritchie (accessed 5 August 2019). 
Röhling M (2018) Kaum steht fest, dass Höcke in der AfD bleiben darf, macht er wieder Stimmung gegen Homosexuelle. Bento, 16 May. Available at:

https://www.bento.de/politik/afd-bjoern-hoecke-macht-stimmung-gegen-homosexuelle-a00000000-0003-0001-0000-000002398159 (accessed 29 December 2018).

Romero MEL (2017) How boys and girls are taught different things about violence. The Conversation, 21 December. Available at https://theconversation.com/how-boys-and-girlsare-taught-different-things-about-violence-87779 (accessed 29 November 2018).

Sager M and Mulinari D (2018) 'Safety for whom? Exploring femonationalism and careracism in Sweden, Women's Studies International Forum 68: 149-156.

Save the Pub (2018) The campaign. Available at: https://www.savethepub.co.uk/thecampaign/. (accessed 5 January 2019).

Schippers M (2007) Recovering the feminine other: masculinity, femininity, and gender hegemony. Theory and Society 36(1): 85-102.

Scarrow SE and Gezgor B (2010) Declining memberships, changing members? European political party members in a new era. Party Politics 16(6): 823-843.

Sherman J (2013) UKIP's only female MEP defects to the Tories. The Times, 23 February. Available at: https://www.thetimes.co.uk/article/ukips-only-female-mep-defects-to-the-torieswwjgrqfe2g6 (accessed 5 January 2019).

Smith, L (2017) LGBT equality has gone 'too far', says new Ukip leader Henry Bolton, Independent, 30 September. Available at: https://www.independent.co.uk/news/uk/politics/lgbt-rights-transgender-equality-too-farukip-leader-henry-bolton-a7975481.html (accessed 5 August 2019).

Spierings N, Zaslove A, Mügge LM and de Lange SL (2015) Gender and Populist RadicalRight Politics: An Introduction Patterns of Prejudice 49(1-2): 3-15.

Stephens J (2017) Toxic masculinity is everywhere. It's up to us men to fix this. Guardian, 
23 October. Available at: https://www.theguardian.com/commentisfree/2017/oct/23/toxicmasculinity-men-privilege-emotions-rizzle-kicks (accessed 15 January 2019).

Stępień, A (2017) Why we need to stop talking about a 'masculinity crisis'. The Conversation, 13 December. Available at: https://theconversation.com/why-we-need-to-stoptalking-about-a-masculinity-crisis-88713 (accessed 29 November 2018).

Stuttgarter Zeitung (2018) Aggression der AfD-Fraktion nimmt zu. 15 December. Available at: https://www.stuttgarter-zeitung.de/inhalt.landtagspraesidentin-muhterem-aras-aggressionder-afd-fraktion-nimmt-zu.97d09ba9-04a3-46aa-b071-a4c64265d920.html (accessed on $30 / 12 / 2018)$.

Swann A (2014) Roger Bird isn't a sexual predator - Ukip men are no worse than other male politicians. Telegraph, 9 December. Available at: https://www.telegraph.co.uk/women/womens-life/11282644/Roger-Bird-isnt-a-sexualpredator-Ukip-men-are-no-worse.html (accessed 4 January 2019).

Swinford S and Heighton L (2014) Revealed: the text messages Roger Bird says proves he was in a relationship with star Ukip candidate. Telegraph, 9 December. Available at https://www.telegraph.co.uk/news/politics/ukip/11282327/Roger-Bird-text-messages-that-hesays-prove-relationship-with-Natasha-Bolter.html (accessed 4 January 2019).

Tapsfield J (2013) Ukip MEP Marta Andreasen defects to the Tories and launches attack on Nigel Farage. The Independent, 23 February. Available at:

https://www.independent.co.uk/news/uk/politics/ukip-mep-marta-andreasen-defects-to-thetories-and-launches-attack-on-nigel-farage-8507960.html (accessed 5 January 2019).

Thomson J (2016) Explaining gender equality difference in a devolved system: The case of abortion law in Northern Ireland. British Politics 11(3): 371-388.

Topping A, Lyons K and Weaver M (2019) Gillette \#MeToo ad on ‘toxic masculinity' cuts deep with men's rights activists. Guardian, 15 January https://www.theguardian.com/world/2019/jan/15/gillette-metoo-ad-on-toxic-masculinitycuts-deep-with-mens-rights-activists (accessed 15 January 2019). 
Ukip (2010) Manifesto, Empowering the People, April. Available at:

http://www.politicsresources.net/area/uk/ge10/man/parties/UkipManifesto2010.pdf (accessed 4 January 2019).

Ukip (2015) Manifesto, Believe in Britain. Available at:

https://d3n8a8pro7vhmx.cloudfront.net/ukipdev/pages/1103/attachments/original/142929505 0/UKIPManifesto2015.pdf?1429295050 (accessed 5 January 2019).

Ukip (2017) Manifesto, Britain Together. Available at:

https://d3n8a8pro7vhmx.cloudfront.net/ukipdev/pages/3944/attachments/original/149569546 9/UKIP_Manifesto_June2017opt.pdf?1495695469 (accessed 5 January 2019).

Usherwood S (2008) The dilemmas of a single-issue party - The UK Independence Party. Representation 44(3): 255-264.

Welt.de (2017) Sexismusvorwürfe auf offener Bühne beim AfD-Parteitag. 3 December. Available at: https://www.welt.de/politik/deutschland/article171209885/Sexismusvorwuerfeauf-offener-Buehne-beim-AfD-Parteitag.html (accessed 30 December 2018).

Wilkinson M (2016) Diane James quits as Ukip leader after just 18 days as Nigel Farage rules out a comeback. Telegraph, 5 October. Available at: https://www.telegraph.co.uk/news/2016/10/04/diane-james-quits-as-ukip-leader-after-just-18days-as-successor/ (accessed 4 January 2019).

Wintour P and Mason R (2014) Nigel Farage says breastfeeding women should sit in a corner. Guardian, 5 December. Available at: https://www.theguardian.com/politics/2014/dec/05/nigel-farage-ukip-claridges-breastfeedingmothers (accessed 5 January 2019).

Women's Studies International Forum (2018) Introduction: feminisms in times of antigenderism, racism and austerity', Women's Studies International Forum, 68: 139-41. 
Zdf.de (2018) Roth und Kubicki - Bundestagsvizes: Aggressive Stimmung durch AfD. 29 December. Available at: https://www.zdf.de/nachrichten/heute/bundestagsvizepraesidentenafd-veraendert-umgangsformen-radikal-100.html (accessed 31 December 2018). Zeit Online (2017) Petry und Pretzell verlassen die AfD. 26 September. Available at: https://www.zeit.de/politik/deutschland/2017-09/frauke-petry-kuendigt-austritt-aus-der-afdan (accessed 11 January 2019). 